\title{
DEVELOPMENT OF CEFTA 2006 - MINI SCHENGEN -ECONOMICS VERSUS POLITICS
}

\author{
Dijana Grahovac ${ }^{1}$ \\ Senad Softić ${ }^{2}$
}

DOI: https://doi.org/10.31410/LIMEN.2020.113

\begin{abstract}
The effectiveness and efficiency of CEFTA 2006, even after almost a decade and a half, are far from utilising the potential. Member States act more as competitors than as partners, manifested by a significant number of formal and informal non-tariff barriers. There is no true will to fully exploit the potential offered by the free trade zone. This is also reflected in the low utilisation of financial resources envisaged for joint cross-border cooperation projects of IPA I and IPA II funds. All countries focus their international exchanges through trade with the EU, and intra-CEFTA trade is focused only on exports. The EU is making efforts to connect more tightly countries by supporting mini-Schengen project for Western Balkans. The paper will try to answer the questions: what economic benefits can the mentioned model bring and is politics a significant obstruction? The comparative regression analysis of the impact of the exchange of goods and services on the economic development of the member states for CEFTA 1992 and CEFTA 2006 will be presented in the paper. The analysis will be done by using the SPSS statistical program.
\end{abstract}

Keywords: CEFTA 2006, Mini Schengen, Countries of Western Balkan, External trade, Economics, Politics.

\section{INTRODUCTION}

The development of international trade today, undoubtedly, represents one of the priorities of the world economies. Moreover, scientific studies are dealing with the relationship between foreign trade and economic development. The scientific study of two professors from the University of Harvard, Sachs and Warner (1995) show that developing countries during the 1970s and 1980s opened their markets to the world, and had an average economic gain of $4.5 \%$, whereas closed economies had only $0.7 \%$. They also stated that developed countries with open economies have economic growth of $2.3 \%$, while those countries with closed economies had only $0.7 \%$ of economic growth.

The same conclusion was reached in a scientific study in 2003 carried by economists Wacziarg and Horn Welch (2003). The fact is that most economists are for developing international trade.

Any economic integration, on an economic basis, towards the creation of a free trade area aims at increasing trade within that region and enhancing competitiveness with the rest of the world. In addition to these goals, the emergence of the CEFTA Free Trade Area in 2006 was also motivated by certain political issues, such as the process of integration of Member States into the EU.

1 Central Bank of Bosnia and Herzegovina and University of Business Studies Banja Luka, Bosnia and Herzegovina

2 Central Bank of Bosnia and Herzegovina and Economic Faculty in Sarajevo, Bosnia and Herzegovina 


\section{THE FOREIGN TRADE COEFFICIENT}

Should small countries fully liberalize their trade with foreign countries? This is a question that in theory is largely no longer being posted. The advantages of integrating into the international trading system are such that autarchy is not a real alternative. Even famous Neo-Keynesians, like Krugman (1993), believe that free trade "though not perfect, is rather good," and that "any attempt to get away from free trade will end up with more harm than good."

The foreign trade coefficient (the coefficient of openness of the economy) measures the overall dependence of the country on foreign trade. It is obtained as a ratio of foreign trade (exports and imports) and gross domestic product. Researcher Daitoh (2008) believes that such policies are a path to the process of poverty reduction in underdeveloped economies and that the economies that are pushing for restrictive policies in international trade are lagging behind and facing a low standard and slow recovery and growth. (Sachs, Warner, 1995; Krueger, 1998; Dollar, Kraay, 2001; Krugman, Obstfeld, 2001). However, numerous researchers expressed doubt about the consistency of the positive link of international trade and economic growth/development (Rodrigez, Rodrik, 2000), mainly as a result of the lack of a conceptual definition of openness and its measurement (Baldwin, 2004).

Dowrick and Duc-Tho (1989) do not doubt that the openness of the economy, even with the elements of protectionism, promotes growth. Thus, the research by these authors points to the fact that the dynamic benefits of trade are indisputable, but there is a possibility that in many countries "immiserizing growth" occurs (growth with impoverishment), i.e. deterioration of the "exchange relationship" because trade liberalization stimulates growth in the world economy (stimulating international flows of knowledge and innovation and "allowing" economies to specialize), but at the same time some economies can specialize in areas where low work qualifications are needed, or in slowly growing sectors ${ }^{3}$.

Table 1 shows the coefficient of openness of the CEFTA countries. There is a high degree of openness, which is not surprising since these are small countries, which have to seek their place in the global market through the exchange.

Table 1. Foreign trade coefficient of CEFTA 2006 countries

\begin{tabular}{|c|c|c|c|c|}
\hline Year/Country & AL & SER & FYRM & B\&H \\
\hline 2008 & 0,9 & 0.8 & 1,1 & 0,88 \\
\hline 2009 & 0,8 & 0,7 & 0,9 & 0,68 \\
\hline 2010 & 0,9 & 0,8 & 1,0 & 0,79 \\
\hline 2011 & 0,9 & 0,8 & 1,1 & 0,88 \\
\hline 2012 & 0,9 & 0,9 & 1,1 & 0,84 \\
\hline 2013 & 0,9 & 0,9 & 1,0 & 0,83 \\
\hline 2014 & 0,8 & 1,0 & 1,1 & 0,87 \\
\hline 2015 & 0,7 & 1,1 & 1,1 & 0,83 \\
\hline
\end{tabular}

Source: Central banks of mentioned countries

3 Possible specialization in " natural resource based activities " reduces educational and 'skills' initiatives 


\section{COMPARATIVE ANALYSES OF INTRA-CEFTA AND EXTERNAL TRADE WITH EU}

The greatest effects of this agreement were visible in the first years after signing (for example, in 2008, the total value of intra-regional export flows was 2.5 times higher than in 2006). However, in the following years, a slower growth rate of intra-regional exchange followed, which throughout the entire 2006-2016 period produced an average annual growth of 7\% (Bjelić, Dragutinović, 2018, 23).

Graph 1 shows a significant decline in intra-CEFTA trade since mid-2013 due to Croatia's leaving the CEFTA market. The decline increased until mid-2015 when a slight increase in intra-CEFTA exchange began. At the end of 2016, the index of exchange with the EU was 250, and intra CEFTA below 200, compared to the essential 100 in 2006.

Graph 1. CEFTA 2006 interregional exports and exports to the EU (Indexes, $2006=100$ )

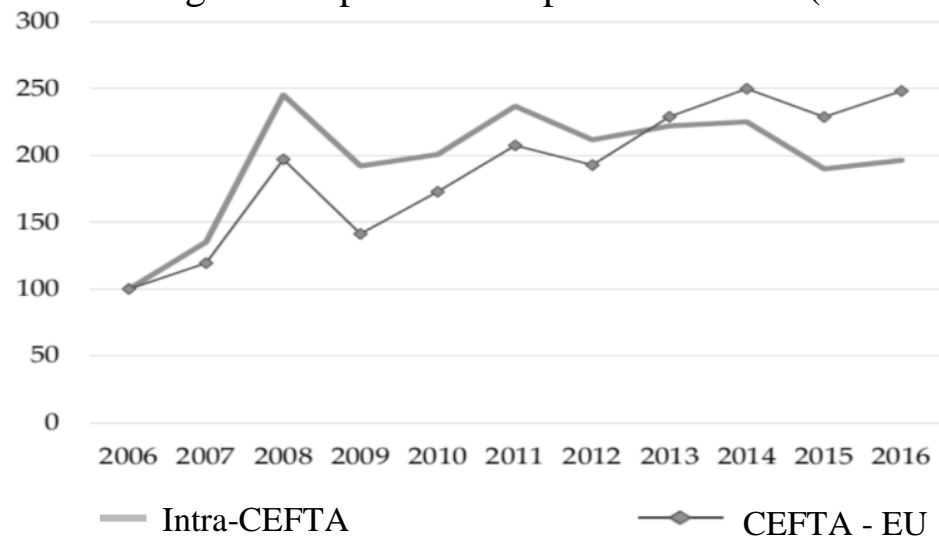

Source: Bjelić and Dragutinović-Mitrović (2018)

The EU was the main partner of the Western Balkan countries, both in terms of exports (72\%) and imports (58\%) in 2018. In 2018, manufactured goods made up $78 \%$ of EU exports and $81 \%$ of EU imports from the Western Balkan countries (graph 2).

Graph 2. External trade between members of CEFTA 2006 and EU

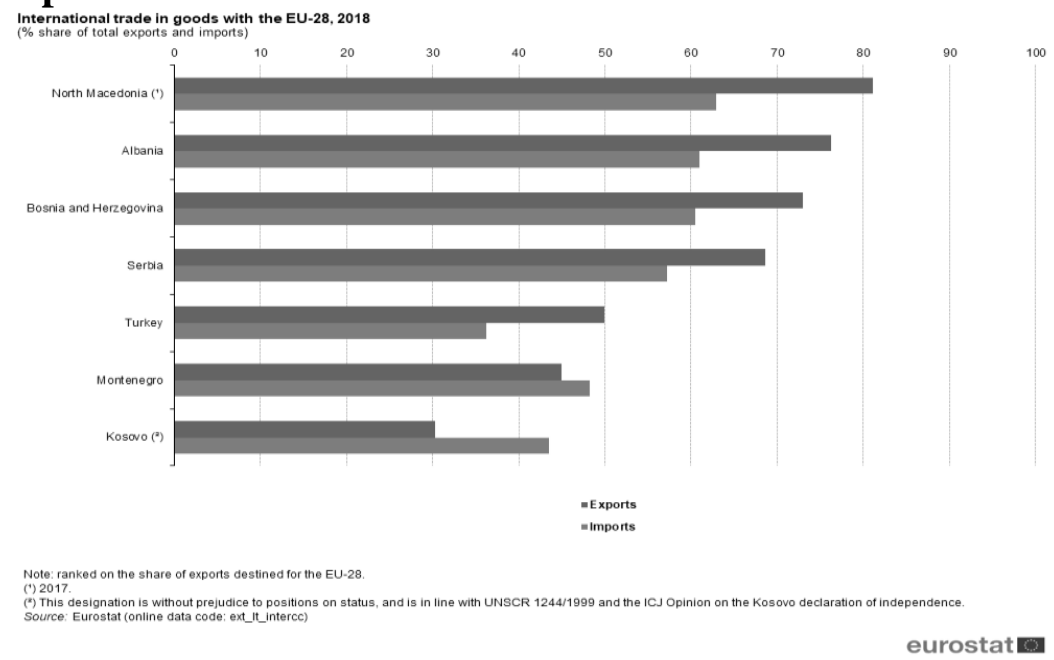

Source:

https://ec.europa.eu/eurostat/statisticsexplained/index.php?title=Western_Balkan_countriesEU_-_international_trade_in_goods_statistics (02.08.2020.) 


\section{ECONOMETRIC ANALYSIS OF THE IMPACT OF FOREIGN TRADE EXCHANGE WITH CEFTA AND EU ON GDP}

The following is an overview of the impact of CEFTA member countries' trade with CEFTA and the EU on the GDP of the countries observed. The model of multiple linear regression will be applied to the formula for GDP.

$\mathrm{GDP}=\mathrm{C}+\mathrm{I}+\mathrm{G}+\mathrm{X}$, where

$\mathrm{C}=$ spending by consumers,

$\mathrm{I}=$ investment by businesses,

$\mathrm{G}=$ government spending and

$\mathrm{X}=\mathrm{Ex}-\mathrm{Im}$ (equals net exports),

adapted to the way in which set all variables to be a constant, except for foreign trade (through exchange with the EU and intra CEFTA). Multiple Linear Regression (R) is used to find out the relationship between mentioned external trade and GDP.

The formula applied is:

$\ln \mathrm{GDPt}=\beta 0+\beta 1 \ln \mathrm{ET} \mathrm{t}+\varepsilon \mathrm{t}$

where

$\beta o=$ Intercept

$\beta 1=$ slope (measure the impact of the dependent variable on the independent variable)

GDP $\mathrm{t}=$ Gros domestic product in period $\mathrm{t}$

ET $\mathrm{t}=$ External trade $(\mathrm{EU}$ and intra CEFTA) in period $\mathrm{t}$

$\varepsilon i=$ Random Error

Table 2 shows the significant linkage of all CEFTA members' trade exchange with EU and CEFTA with GDP, with very high coefficients.

Table 2. Model Summary of influence intra CEFTA 2006 trade and CEFTA 2006 with EU trade on GDP

\begin{tabular}{|l|c|c|c|}
\hline Country & R & R Square & Adjusted R Square \\
\hline Albania &, $976^{\mathrm{a}}$ &, 953 &, 941 \\
\hline B\&H &, $973^{\mathrm{a}}$ &, 946 &, 933 \\
\hline N. Macedonia &, $825^{\mathrm{a}}$ &, 680 &, 600 \\
\hline Serbia &, $919^{\mathrm{a}}$ &, 845 &, 806 \\
\hline
\end{tabular}

a. Predictors: (Constant), EU, CEFTA

b. Dependent Variable: GDP

If the volume of trade between CEFTA and the EU is separated (Table 3), there is incomparably lower importance of the exchange with CEFTA concerning the EU, where the coefficient is even above 1 in cases of some countries. Negative coefficients in the case of Albania and S. Macedonia express their primary orientation to the EU market.

Table 3. Coefficients of correlation - separately, trade CEFTA-EU; intra CEFTA trade

\begin{tabular}{|c|c|c|}
\hline Country & EU & CEFTA \\
\hline Albania & 1,065 & $-0,93$ \\
\hline B\&H & 1,071 & 0,242 \\
\hline N. Macedonia & 0,795 & $-0,134$ \\
\hline Serbia & 0,919 & 0,203 \\
\hline
\end{tabular}




\section{THE (UN) SUCCESS OF CEFTA 2006 AND THE PERSPECTIVE OF THE "MINI SCHENGEN"}

The economic situation in CEFTA is difficult to separate from the political because economic flows are built on political grounds. It is therefore not surprising that Serbia has the highest volume of exchanges with B\&H (Republic of Srpska) and vice versa, then with North Macedonia, while Albania has the largest exchange with Kosovo. On the other side, Kosovo has the largest volume of exchanges with Serbia (the unresolved status of Kosovo) and then with North Macedonia (a significant number of Albanian population) and Albania.

Table 4. Intra - CEFTA trade in period 2012-2018

\begin{tabular}{|l|l|l|l|l|l|}
\hline & B\&H & SER & AL & NM & KOSOVO \\
\hline B\&H & - & 9419 & 204 & 949 & 572 \\
\hline SER & 9419 & - & 857 & 4887 & 2795 \\
\hline AL & 266 & 857 & - & 730 & 1320 \\
\hline NM & 1192 & 4887 & 730 & - & 1670 \\
\hline KOSOVO & 740 & 2795 & 1320 & 1670 & - \\
\hline
\end{tabular}

Source: CEFTA Secretariat, https://statistics.cefta.int/goods

Due to the growing political tensions and the refusal of an increasing number of EU countries to integrate the Western Balkans countries into the EU, official Brussels decided to strengthen efforts to create the so-called Mini Schengen for the mentioned countries. The countries of the region are also covered by the process of stabilization and accession to the European Union, which means that they are on the path to full membership, although this path is very slow in their case. Montenegro and Serbia are candidates for membership and they have been negotiating entry for years, but their entry, according to the latest available information, is not expected before 2025. Albania and Northern Macedonia have candidate status and they are just at the beginning of the negotiating saga, while B\&H and Kosovo are still only potential candidates. In the very slow process of joining the EU, many see the real reason for the creation of the Balkan mini Schengen: an area that should accelerate trade and commerce between the countries of the Western Balkans, but also those regions with the rest of Europe. The goal is to remove obstacles to the exchange of goods and services between the countries of the region, as well as the free movement of the population.

The project mini Schengen implies the establishment of a common market and a single investment destination with harmonized regulations and simpler rules in the Balkans, which would facilitate and accelerate the crossing of borders between the countries of the region, which is one of the biggest problems due to long waits and high costs. In the first phase, the project includes three signatory countries, and in the second phase, it should include Bosnia and Herzegovina, Kosovo and Montenegro. Among other things, it provides for the possibility of crossing borders only with ID cards, and unique work permits will be introduced as well.

If there was a mini-Schengen and if the EU stimulated the funds, then through the participation of countries and regional integration, bilateral problems would be reduced, regional infrastructure would be strengthened or built and economic systems would be improved.

Application of the mini Schengen could show that the region is not a burden for the EU, but that it requires significant concrete reforms in each of the countries - in the field of labor legislation, immigration and customs policies, judicial reform, especially when it comes to the 
collection of claims and respect for workers' rights, which would be the same for everyone in the region.

Mini Schengen could also significantly alleviate the problem that the Western Balkan countries have now with economies of scale. On the one hand, the free flow of people and goods means a more attractive market of almost 20 million consumers, and on the other hand, by pooling production capacities, the problem of insufficient production volume could be overcome due to which the companies from each country cannot compete in larger markets which are looking for larger quantities of goods.

Increased cooperation between the countries of the region could increase the inflow of foreign direct investment and the region's networking with the West. It would be most desirable for the countries of the region to merge production capacities and export products provided that there are no excessively large political obstacles.

\section{CONCLUSION}

The CEFTA 2006 region is very complex, viewed through the prism of historical sociopolitical relations. Numerically small nations, expressed needs for national identity, in the territories that have been under occupation for centuries, accentuate primarily the achievement of political goals, and economic relations have put under them. Unfortunately, in this way, economic development is blocked and the population is trapped in the political sphere. The result of such processes is a pronounced migration of the population of all countries in the region to the EU and other developed countries.

Observing the level of trade and investment in the region in 1998, Gligorov found that rather than shifting trade to the region, historical divisions and rivalries discouraged Balkan countries from integrating into regional trade relations and prevented them from using geographical proximity as a means of increasing profits and profits.

Importance of the involvement of all countries in the flow of international trade is important for every national economy. This is particularly obvious in small countries, which cannot be self-sufficient. This is the case with Bosnia and Herzegovina, as well as with all the countries in the region. Regarding $\mathrm{B} \& \mathrm{H}$, from all of the above, it follows that the EU market is dominant for $\mathrm{B} \& \mathrm{H}$, and that the potential for the CEFTA zone has not been fully utilized.

The emergence of political problems diminishes the chances of increased export of Serbian businesses to the countries of CEFTA 2006, so it needs to work on stabilizing the political situation in the region and then on new forms of trade and investment cooperation in the regions that precede the accession to the EU (Bjelić, Dragutinović, 2018, 6).

Considering the low level of efficiency of CEFTA 2006, the "mini Schengen" zone should strengthen and deepen economic activities between the countries of the Western Balkans, but also stabilize the political situation. The goal to be achieved is economic and political stabilization with the purpose of effective preparation for the integration of the entire region into the EU. Whether economic interests, supported through EU projects, will prevail or whether political tensions will obstruct the project, the time will show. 


\section{REFERENCES}

Baldwin, R.E., Openness and growth: What's the empirical relationship?. In Challenges to globalization: Analyzing the economics (pp. 499- 526), University of Chicago Press, 2004.

Bjelić, P., Dragutinović-Mitrović R., Unaprijeđenje pozicije Srbije u okviru CEFTA 2006, Belgrade, 2018.

Daitoh, I., Environmental Protection and Trade Liberalization in a Small Open Dual Economy, Review of Development Economics, Vol. 12, Issue 4, pp. 728-736, November 2008

Dollar, D., \& Kraay, A., Trade, growth, and poverty, World Bank, Development Research Group, Macroeconomics and Growth, 2001

Dowrick, S., Duc-Tho, N., OECD Comparative Economic Growth 1950-1985: Catch-Up and Convergence. American Economic Review, 79 (5): 1010-1030, 1989

Gligorov,V., Trade and Investment in the Balkans, in Vladimir Gligorov and Hermine Vidovic, On the Way to Normality - The States on the Territory of Former Yugoslavia in the Postwar Period, WIIW Paper no. 250, October 1978, str. 1 - 7 . See: www.wiiw.ac.at/balkans/files/gligorov.pdf

Krueger, A., Why trade liberalisation is good for growth, The Economic Journal, 108(450), 1513-1522, 1998;

Krugman, P., Obstfeld, M., Rev. ed. of International economics: Theory and Policy, Pearson Series in Economics, 2009;

Krugman, P., On the Relationship Between Trade Theory and Location Theory, Review of International Economics, p 364, 1993.

Međak, V. (editor) Effects of Stabilisation and Association Agreements and CEFTA2006 on WB6 European Integration and Regional Cooperation: Achievements and Ways Forward, European Movement in Serbia, Belgrade, 2018

Rodriguez, F., Rodrik, D., Trade policy and economic growth: a skeptic's guide to the crossnational evidence, In NBER Macroeconomics Annual 2000, Volume 15 (pp. 261-338). MIT Press, 2001;

Rodrik, D., Subramanian, A., Trebbi, F., Institutions rule: the primacy of institutions over integration and geography in economic development, 2002;

Sachs, J.D., Warner, A., Economic reform and the process of global integration Brook. Pap. Econ. Act., 1 (pp. 1-118) 1995.

Sachs, J.D., Warner, A., Economic reform and the process of global integration Brook. Pap. Econ. Act., 1 (pp. 1-118) 1995;

Wacziarg, R., Horn Welch, K., Trade Liberalization and Growth: New Evidence, NBER Working Paper No. 10152, Issued in December 2003. 